with Williams and Naudé, the war is a pretext to consider its impact on the post-war and post-apartheid periods.

The next group of nine articles reveals more historiographical characteristics. These are the paper by Mariaan Roos and Ian Liebenberg on the suffering of animals in the war and two articles by Jabulani Maphalala on the participation of Africans - black people - in the war and the consequences of the war on this section of the South African population. There is also the paper by Louis Changuion on the origins of the negative relationships between the Boers and the local black tribes during the war and its consequences into contemporary South Africa. Bernard Magubane returns once again to the classic topic of the relation between gold and Anglo-Boer War and Arlene Grossberg and Ian Liebenberg write on the history of the city of Pretoria while Gert van der Westhuizen discusses rugby matches as an extension of the war at the turn of the $19^{\text {th }}$ and $20^{\text {th }}$ centuries.

In the last group four articles explore the international links of South Africa with Ireland (Gert van der Westhuizen), with Russia (Apollon Davidson and Irina Filatova), with Holland (an outstanding article by Vernon February) and one on the activities of an emergent Red Cross Society (Kay de Villiers). Two analytical articles by Ina Snyman, one on memoirs, the second on the consequences of the Anglo-Boer War and lastly her epilogue with suggestions for new studies and fresh views, conclude A Century is a Short Time.

It is praiseworthy that the compilers intended the book to cover a broader scope on the war, i.e. a sample of diverse views on the war and even more important to extend their brief to writers outside the field of professional historians. However, the reasons for this set of authors and the selection of the specific topics should have been stated much clearer. If the reader does not know why these specific writers or their topics were chosen he/she will be none the wiser about these selections or omissions, for example what about the participation of Indian people in the wari.e. Mohandas Gandhi and his followers - or the participation of countries like Germany or France?

Although the compilers in their introduction clarify the effects of the Anglo-Boer War and its imprint on current South Africa with the phrase that a century is a "very short time in the history of any nation" I suspect that the title of the book does not reveal the wealth of the book. The book is a demonstration of the richness of analysis, diverse points of view, interesting approaches and useful suggestions for future research. May I suggest that the authors demonstrated thoroughly that one century is enough to look back, to meditate and to look into the future?

\author{
Marisa Pineau \\ Universidad de Quilmes, Buenos Aires; \\ Universidad de Buenos Aires, \\ Buenos Aires, Argentina
}

\section{Room 207.}

Moele Kgebeti. Cape Town: Kwela Books. 2006. 238 pp. ISBN 0-7957-0234-5.

Moele Kgebeti gives an eyewitness account of black experience in South Africa's city of dreams, Johannesburg, focussing on the experiences of the occupants of Room 207, namely, the first person narrator, Molamo, D'nice, Modishi, the Zulu boy and Matome, all university dropouts who came to the city in search of success in life through education. Of interest in this narrative is the fact that the Johannesburg that Kgebeti vividly paints is identical to that of Can Themba of the Drum decade, forty decades earlier, depicted in stories such as "Kwashiorkor, "The Suit", "Mob Passion" and "Marta", to mention a few. 
Like Themba's Johannesburg of the 1960's, it attracts the occupants of Room 207 "wooingly", "alluringly" like a lover giving them false hope that all their dreams will be realised. In reality the opposite is true, for the life it offers its occupants is cold and cruel. The instability and transitory nature of their lives is suggested by the words "stay", "temporary" and "locker room" that are used in chapter one to describe their "long sojourn" in Room 207. The coldness of Johannesburg life, which is portrayed in terms of binary oppositions of predator and prey, is best summed by Justice, the vagrant, thus: "Life is treacherous quicksand with no guarantees" (32). In Justice's case, (previously known as Ice) this has certainly been the case as he started off his life in the dream city as a well to do young man "with a car, a flat, a washerwoman, a billion friends and saw the underwear of almost all the girls who were going to Wits". The narrator describes the cruelty Johannesburg city meted to Justice thus: "It took him three years, some expensive sports cars, which were written off, some expensive fashion, some travelling around this God's green earth, a hundred thousand rands' worth of drugs and alcohol, an innumerable number of orgasms, and then, finally, it was all gone, together with his mind." (30)

A prominent feature of black life that drives black people in droves to cities in general and to Johannesburg in particular, is poverty. The narrator confirms this by describing Johannesburg thus:

It's dream city and here dreams die each and every second, as each and every second dreams are born. However, beyond counting dreams, they all have one thing in common: money. Respect and worship are the ultimate goals; everybody here is running away from poverty. (19)

The former homelands in which all black people were assigned to live during the apartheid era, offered little or no possibilities for employment. A typical black family in those days, according to the narrator, consisted of a mother who worked in the city as a "washerwoman", "a father who, at fifty one, was already on the blue card" (unemployment benefits) and, if one were lucky, a grand parent or two, who helped with pension money, seven siblings, most of them at school, while some were out of school due to lack of money. Undoubtedly, in such circumstances, sending a child to university added more strain to the already exhausted income of the families living on the bread line. Added pressure from the institution immediately after admission worsened the ability to cope for the disadvantaged student concerned:

Then you get admitted to the great institution and, before even three months have passed the last cent from the blue card is gone" leaving the student concerned with no pocket money and the institution repeatedly "reminding you that you need to pay your fees or you are out. (35)

Thus as is currently the case, poverty, peer pressure, isolation of the individual and stress soon take a toll on the student concerned, resulting in many of them dropping out of university as is the case with the occupants of Room 207, thereby shattering their dreams (and those of their parents) of a successful future. In this novel, the effects of poverty are also evident in the overcrowded room which they share and in the lack of basic amenities such as a refrigerator, TV, enough beds, and food.

Other aspects of Johannesburg which this novel vividly portrays, are the fast pace and danger associated with life in the city. According to the narrator, lack of vigilance at any time could be costly and thus requires one to "walk carefully and think fast" for "you are either fast or dead". In such unpleasant living circumstances, booze, sex and parties enable city dwellers in general and occupants of 
Room 207 in particular, to escape the dreariness, which is a prominent feature of these characters" lives. For example, it is a common occurrence for these youngsters to spend the money meant for rent and food on drinking and partying. While this could denote reckless and irresponsible behaviour, for them drinking is also a form of escape.

Johannesburg social life as portrayed in this novel is characterised by promiscuity of alarming proportions. In Room 207 a girlfriend passes from one roommate to the other like a soccer ball during a game. Love relationships are not serious; instead love is treated as a game in which players merely take turns. Love for the occupants of Room 207 is devoid of genuine emotion. In Matome's words it is confused with sex, which according to him, is merely an act which soon ends, unlike love which is a "process" which does not end. The promiscuous behaviour that is displayed by the characters is especially frightening in a country where official statistics suggest that HIV is infecting and affecting huge numbers of people. The fact that these characters carelessly engage in sexual escapades, even though they use condoms, is disturbing as condoms are not totally reliable. Even the "one-woman man", Modishi, is not immune from this careless behaviour as he stops using condoms and tricks his girlfriend, Lerato, into pregnancy because of a dare by his friends. This could be indicative of the fact that although knowledge of HIV infection is readily available, the material pressures of urban life over-determine popular, especially male, behaviour. Accordingly conditions of life lead to risk-taking behaviour.

That the occupants of Room 207 are a bunch of gifted people is beyond question. It is precisely this quality that has driven each and every one of them from the rural "homelands" of South Africa to seek an education that would hopefully open doors to a better tomorrow in the city. However, they all find the institutions of higher learning hostile. This results in alienation and loss of a sense of self, which eventually drive most of them out of the institutions of higher learning. Of interest too is the fact that although the dream of achieving success through education fails, their dreams to succeed in Johannesburg (where anything can be achieved) and survive in life do not, resulting in many of them seeking success by hook or by crook. Matome, "the owner/manager of a recording company cum printing house cum artist management agency cum everything", is a case in point. Although at first perceived to be no more than a "foolish" boy by the narrator and effeminate by all, Matome proves to be the most streetwise, and consequently the first one to survive Hillbrow and host an "out of Hillbrow party". Subsequently, the occupants of Room 207 move out of Hillbrow at different times. A kind of love and hate relationship between the occupants of Room 207 and Hillbrow, the place where the novel is set, exists. From the description of Hillbrow and Room 207, one can see that the narrator does not deem the place fit for human habitation, yet the fact that he loves it is evident too. For example, he describes Room 207 as a "damp and crumbling [...] haven" and invites readers to "smell the contaminated Hillbrow air".

An equally important characteristic of black experience that Kgebeti exposes in this novel is the issue of self-hatred and lack of self-respect which many black South African writers from the Drum decade have written about. The narrator and the other occupants of Room 207 suggest that the dirty surroundings in which blacks live are proof of lack of self-love (self-hatred) and lack of self-respect since city cleaners are black. Evidence of lack of self-love and self-respect according to the Zulu boy is expressed in the quotation below:

How can it be that blacks were and are still cleaning this city but it is rotting today? We 
black people are the majority of city cleaners the world over, but we can't clean our very own city? Why? Because a black man doesn't have even a tiny amount of respect for another black man. Look at how clean Sandton and all the other white suburbs are and no white man cleans there, they are cleaned by our very own black people. If we all moved to Sandton today, I give us four weeks only and it will all look like this. (91)

Lack of self-love or self-hatred in black South Africans is also evident in their hostility and xenophobia towards black foreigners. This is evident when the narrator accuses Nigerians of corrupting the rainbow nation and the Zulu boy's outward hostility to Joseph the Zaïrian lekwerekwere (a derogatory term for black foreign nationals).

Lastly, Moele Kgebeti's literary style makes the novel both enjoyable and reader-friendly. Using a conversational mode, Kgebeti takes readers on a journey through Hillbrow. He offers readers a lived in experience of how life is for Blacks living in Hillbrow. In so doing, he engages them to take part, solicits their views and encourages them to make social commentary on black life. I recommend the novel highly for promoting understanding across racial and cultural divides.

\section{Khulukazi Soldati-Kahimbaara}

University of Pretoria, Pretoria

\section{Ja!}

Stef Bos. Pretoria: Protea Boekhuis; Lannoo. 2006. 96 pp. ISBN: 978-1-920042-03-5.

$J a !$ is die tweede publikasie van Stef Bos en vertoon heelwat ooreenkomste met sy eerste geskrewe projek, Gebroke sinne (2004). Soos wat Gebroke sinne deur Marianna Booyens geillustreer is, is die kunstenaar Eric de Bruijn by Ja! betrek. Die uitleg is ook eenders aan dié van Gebroke sinne. In teenstelling egter met die vroeëre publikasie wat volledig uit Nederlands in Afrikaans vertaal is, is Ja! grotendeels in Nederlands geskryf met enkele Afrikaanse tekste. Teen dié tyd is Bos se teikenmark, wat bekend is met sy musiek, waarskynlik genoegsaam vertroud met Nederlands om sy tekste sonder te veel moeite te verstaan. Ongelukkig begaan hy'n paar keer die fout om Nederlandse uitdrukkings in sy Afrikaanse tekste te gebruik wat nie in Afrikaans bestaan nie, byvoorbeeld in "Monoloog in twee kleure" $(38,39)$ : "bang vir hulle ongelyk" (my kursief).

Bos en De Bruijn lê die "program" agter Ja! taamlik duidelik uit. Die teks op die agterblad ("My taal") gee iets weer van 'n vrugbare wisselwerking wat ontstaan wanneer teks en beeld gejukstaponeer word. So ook die teks van Frank Boeijen, "voor de schrijver en de schilder" (7), die kort teks deur Eric de Bruijn waarin hy beweer "het woord / het beeld / het is om het even" (8) en die teks van Bos "Op een dag" langs Boeijen se teks (7). Daarvolgens kry De Bruijn as kunstenaar dit reg dat letters "die taal agter hulle laat" en bloot weer lyne van ink op papier word. Dit verklaar een aspek van De Bruijn se kunswerke in die boek, naamlik dat hulle grotendeels uit letters en woorde bestaan. Verder is hulle collages van foto's en drukwerk van die eerste paar dekades van die twintigste eeu, iets wat op die laaste bladsy van die boek beklemtoon word met 'n fragment uit een van Bos se tekste: "Alleen de foto's van vroeger / Vertellen / Dat er ooit / Een andere wereld was".

Van die drie afdelings in die boek bevat "Het begin" die belowendste tekste waarin die toekoms, 'die begin' telkens ironies kontrasteer met eindes en die verlede, byvoorbeeld in die gedig genommer 1: "We zoeken / in de toekomst / naar een begin / dat wij zijn verloren/in het verleden" (71). Ook in die res van die boek gaan dit dikwels om teenstel- 